U. S. Nat. Mus. (Collection Hubbard \& Schwarz).

I have seen several hundred specimens, discovered by Mr. H. G. Hubbard in the dry pulp of Cereus giganteus. All the specimens came from a single cavity in a decayed trunk, December, 1896 .

This singular Scolytid is at once recognizable from the structure of the thorax and the remarkable cephalic armature in the male. Its affinities and systematic position have, however, remained obscure to me, and the elucidation of these points must be left for future studies. ${ }^{*}$ Its food-habits and mode of development also deviate from those of other Scolytidae. The dry pulp of Cereus giganteus in which this species lives is of a very peculiar nature and resembles certain species of hard Agarics more than a piece of wood. This pulp is extremely hard and brittle, and having examined several pieces sent me by Mr. Hubbard I fail to recognize any regularity or system in the borings of the beetle and its larva. Imagos, pupae and larvae are to be found indiscriminately scattered in the irregular chambers and galleries with which the interior of the pulp is honey-combed.

\title{
Classified List of Species Observed by H. G. Hubbard on the Giant Cactus.
}

BY E. A. SCHWARZ.

\section{Hymenoptera.}

Polistes flavus Cresson.

\section{Coleoptera.}

Dactylosternum cacti Lec., Pelosoma capillosum Lec., Megasternum cerei Sz., Tyrus elongatus Brend., Trimium puncticolle Lec., Eumicrus lucanus Horn, Maseochara semivelutina Solsky, M. spacella Sharp, M. puberula Casey, Aphelogossa rufipennis Casey, unknown genus of Aleocharinae, Hornalota sp. sp., Falagria sp., Oligota n. sp., Xanthopygus cacti Horn, Belonuchus ephippiatus Say, Xantholinus dimidiatus Lec., Lithocharis tabacina Casey, Physeto-

* Prof. A. D. Hopkins of Morgantown, W. Va., has consented to make a thorough investigation of this Scolytid. He has just now (February $\mathbf{r}_{3}, \mathrm{r} 899$ ) forwarded to me a series of careful drawings illustrating the structural details of Cactopinus, but $\mathrm{I}$ am unwilling to anticipate the conclusions derived from his studies. Dr. J. B. Smith has also kindly prepared sketches and microscopic slides illustrating the mouthparts and other details. porus grossulus Lec., Erchomus convexus Er., E. punctipennis Lec., Omalium cacti Sż, Trichopteryx sp. sp., Ditoma gracilis Sharp, D. sulcata Lec., Bothrideres cactophagi Sz., Ephistemus cactophilus Sz., Attagenus hornii Jayne, Hololepta yucateca Mars., H. cacti Lec., H. vicina Lec., Paromalus opuntiae Lec., P. consors Lec., P. gilensis Lec., Acritus arizonae Horn, Holoparamecus pacificus Lec., Alindria teres Melsh., Lycaina discoidalis Horn, Clerid larva (not bred), Monilema giganteum Lec., Ulosonia marginata Lec., Cynaeus angustus Lec., Platydema inquilinum Linell, Cactophagus validus Lec., Apotrepus densicollis Casey, Cossonus hubbardi Sz., Cactopinus hubbardi Sz.

\section{Lepidoptera.}

Melitara fernaldialis Hulst. Larva feeding on decaying pulp of the Giant Cactus. Imagos were bred by Hubbard and myself at Catalina Springs, Ar., in April 1898. 


\section{Diptera.}

Ceratopogon sp., Scatopse sp., Volucella avida O. S., Nerius flavifrons Big., Drosophila sp., Limosina sp.

\section{Orthoptera.}

Spongophora brunneipennis Serv.

Neuroptera.

Termes flavipes Koll.?
Heteroptera.

Brochymena obscura H. S., Dendrocorus contaminatus Uhler, Narnia femorata Stal, Sinea raptoria Stal, Diplodus luridus Stal.

Acari.

Gamasidae (two species obtained from rotten cactus pulp sent by Hubbard to Washington).

Pseudoscorpionidae.

Chelifer n. sp., Chelanops sp.

\section{A NEW VOLUME OF PSYCHE}

began in January, 1897 , and will continue through three years. The subscription price (payable in advance) is $\$ 5.00$ per volume, or $\$ 2.00$ per year, postpaid. Numbers are issued on the first day of each month. Libraries and individuals generally ordering through subscription agencies (which only take annual subscriptions) will please notice that it is cheaper to subscribe for the entire volume at once directly of us.-Any early volume can be had for $\$ 5.00$, unbound. Address Psyche, Cambridge, Mass.

Vols. 1-7, Complete, Unbound $==-=-$ - \$33.00.

Vols. 1-7, and Subscription to Volume $8=-=$ - $=\mathbf{\$ 3 7 . 0 0}$.

Vol. 7 contains over $500 \mathrm{pp}$. and Io plates, besides other illustrations.

\section{The Butterflies of the Eastern United States and Canada.}

With special reference to New England. By Samuel H. Scudder.

Illustrated with 96 plates of Butterflies, Caterpillars, Chrysalids, etc. (of which 41 are colored) which include about 2, o0o Figures besides Maps and portraits. I958 Pages of Text.

Vol. I. Introduction; Nymphalidae.

Vol. 2. Remaining Families of Butterflies.

Vol. 3. Appendix, Plates and Index.

The set, 3 vols., royal 8vo. half levant, $\$ 75.00$ net .

HOUGHTON, MIFFliN \& CO., 4 Park St., Boston, Mass. 

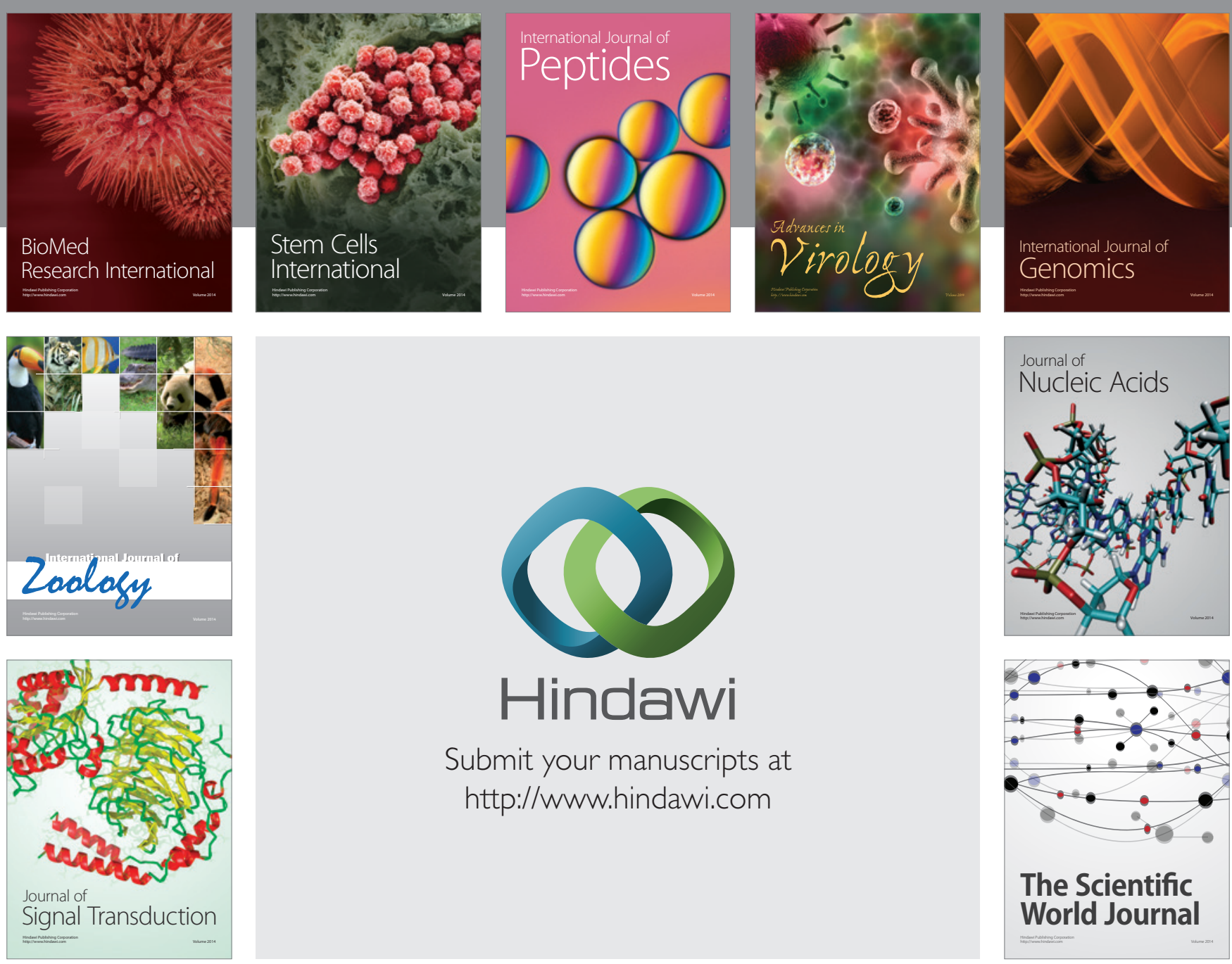

Submit your manuscripts at

http://www.hindawi.com
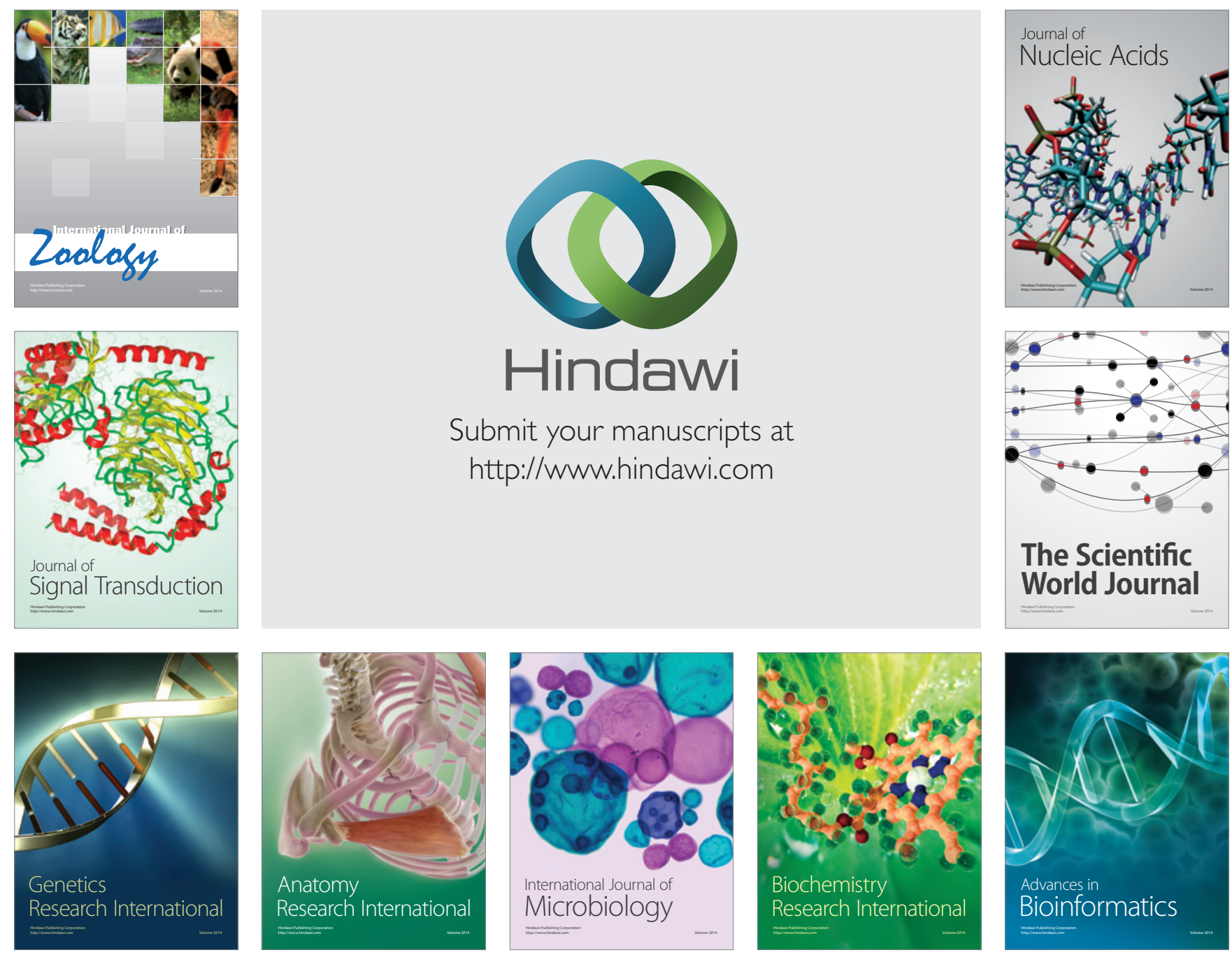

The Scientific World Journal
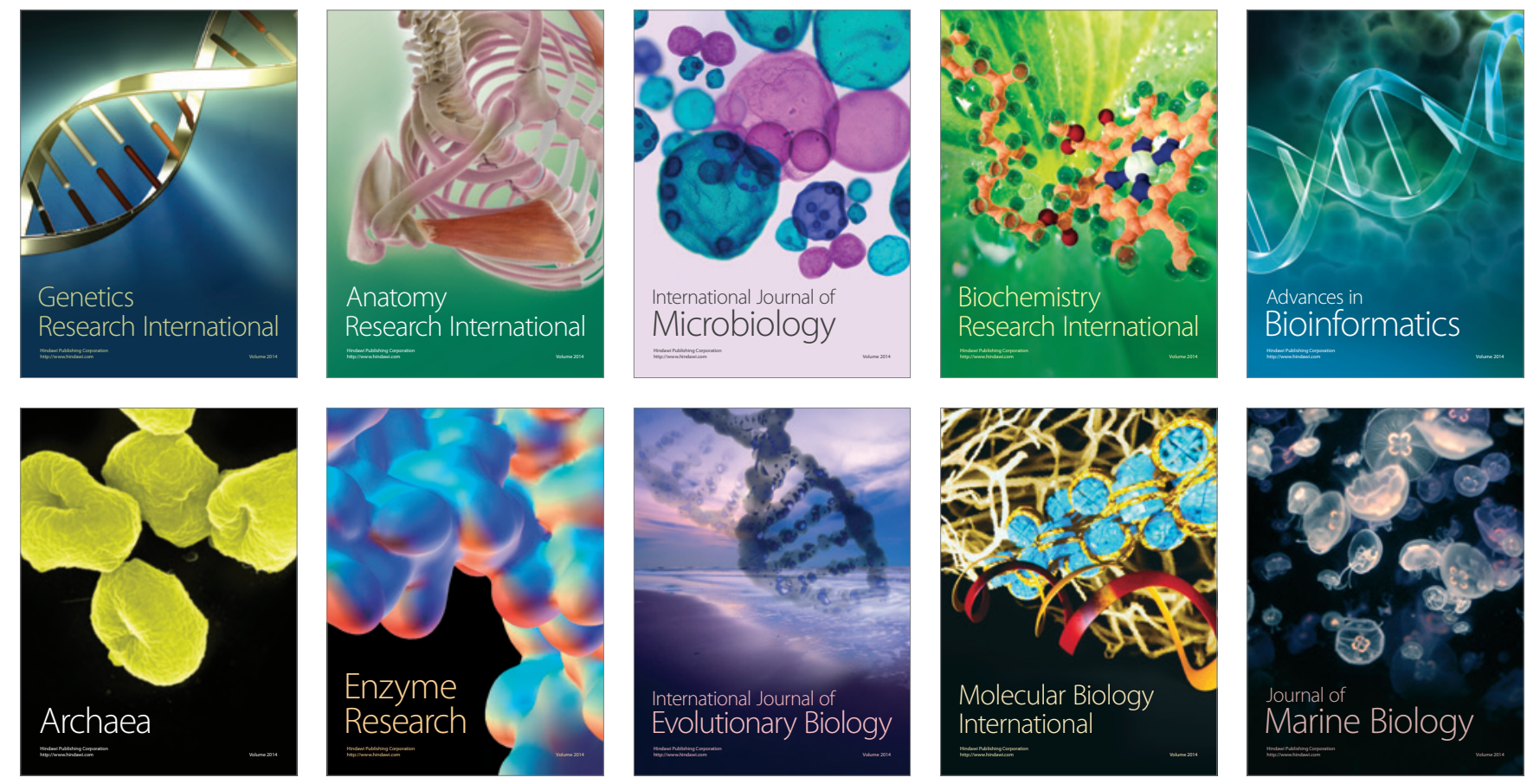